\title{
Endovascular correction of ascending aortic pseudoaneurysm - Case report and concise review of the literature
}

Lucas Regatieri Barbieri*, Thais Amarante Couto, Eliane Cruz, Rubens Andreole Carvalheiro, Oscar Jaime Morales Medranos and Noedir Antônio Groppo Stolf

Hospital BP - A Beneficência Portuguesa de São Paulo, Brazil

\begin{abstract}
A common complication that has been reported after cardiac surgery is the Aortic pseudoaneurysm (PSAs). The safety and efficacy of endovascular therapies for this pathology is still controversial. However surgical management of aortic PSAs is associated with high mortality and morbidly and in some cases is not even feasible so percutaneous closure has been described as an alternative.

In this paper, we present a review of the literature and a case of an endovascular replacement of Aortic PSAs after aortic valve replacement.
\end{abstract}

\section{Introduction}

Aortic pseudoaneurysm is a common complication that have usually been reported after thoracic surgery, including coronary artery bypass grafting, aortic valve replacement, orthotopic cardiac transplantation and aortic dissection repair.

Aortic PSAs are associated with anastomosis or cannulation of the vessel, leading to a poor healing process and defects in the layers of the wall w. Additionally, traumatic, inflammatory, or infectious event can be associated with the development of aortic PSAr.

\section{Case report}

A 67 years old female was referred to the service with an aortic bioprotheses dysfunction. She was reoperated and another pericardial bioprotheses was implanted. The patient had an uneventful recovery. After three months, she was readmitted with bleeding through sternal incision. A CT scan showed a pseudoaneurysm of distal ascending aorta (Figures 1-3). The patient was reoperated with hypothermia and circulatory arrest. The lesion was in the previous aortic canulation

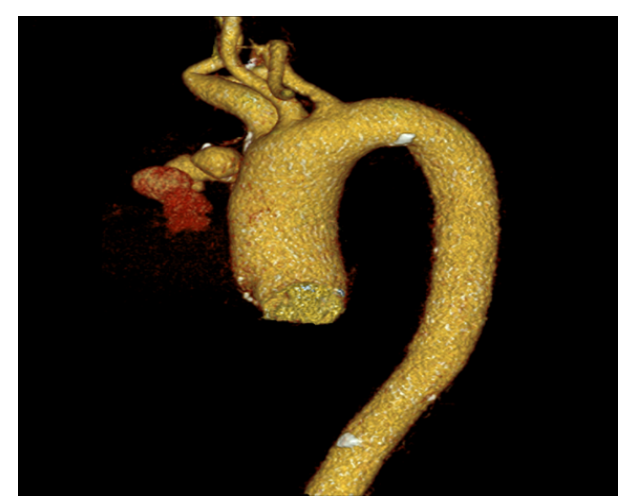

Figure 1. Computed angiotomography: ascending aortic pseudoaneurysm in its distal portion

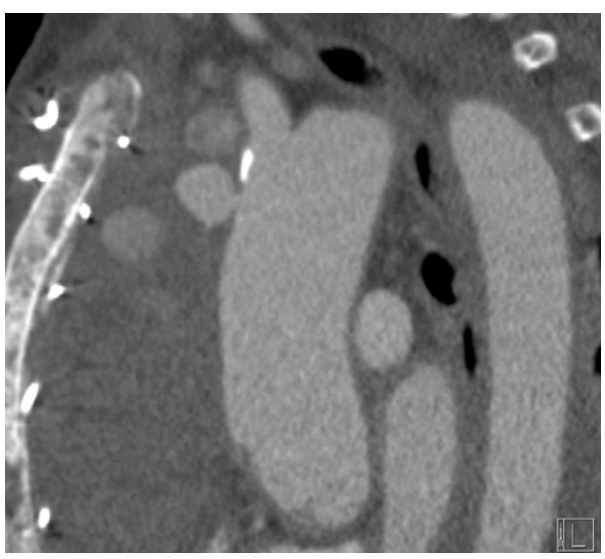

Figure 2. Computed angiotomography: ascending aortic pseudoaneurysm at its distal portion

site and it was closed with pledget stiches and a pericardial patch sutured around. After a few days, the patient had another bleeding in the incision and CT scan showed similar pseudoaneurysm. Due to the fragile tissue in aneurysm neck, an endovascular procedure was indicated through the ventricular apex. A guide wire was introduced in the right subclavian artery until brachiocephalic trunk. A pigtail catheter was positioned in coronary sinus of Valsalva through femoral artery. A Gore-Ctag endoprothesis was introduced through a purse in left ventricle apex and it was positioned with the aid of angiography and

*Correspondence to: Lucas Regatieri Barbieri, Real e Benemérita Associação Portuguesa de Beneficência de São Paulo, R Maestro Cardim, 769 - Bela VistaSão Paulo, SP, Brazil, E-mail: drlucasbarbieri@gmail.com

Key words: aneurysm, endovascular, pseudoaneurysm, aorta, reoperation

Received: June 15, 2018; Accepted: June 21, 2018; Published: June 30, 2018 
transesofageal echocardiograph (Figures 4-7). The control angiography showed excellent result. The patient had an excellent post-operative recovery and was discharged in the 7th day. One month later, CT scan showed complete occlusion of pseudoaneurysm (Figures 8-9).

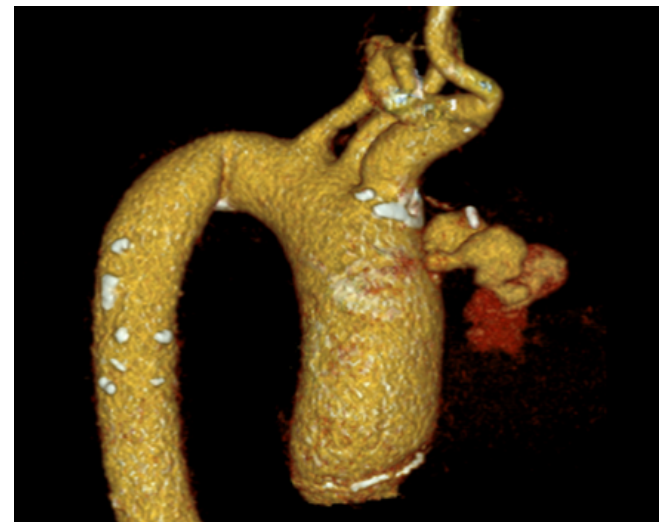

Figure 3. Computed angiotomography: ascending aortic pseudoaneurysm at its distal portion

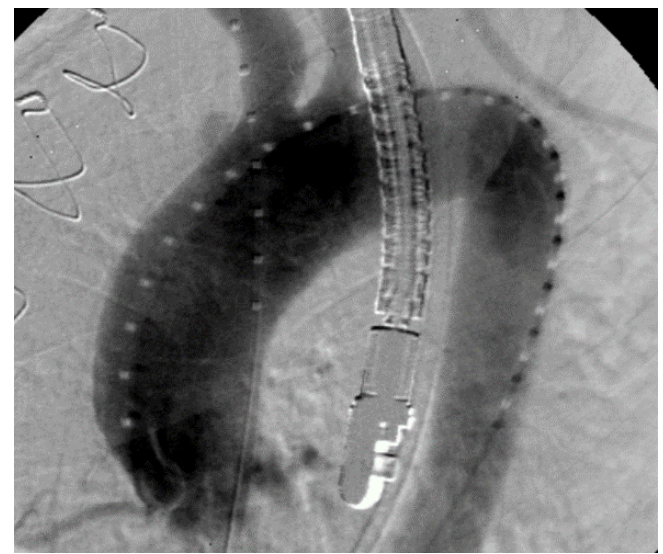

Figure 4. Aortography: ascending aortic pseudoaneurysm in its distal portion, presence of transesophageal echocardiogram

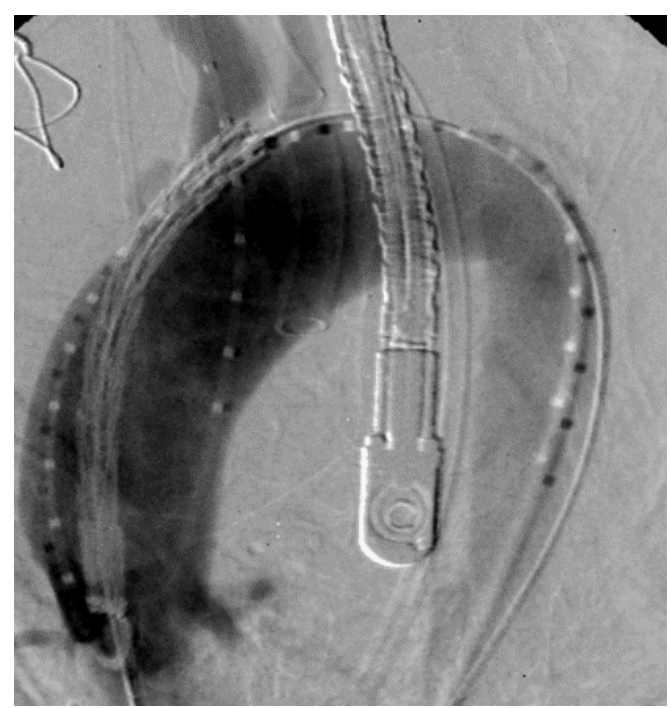

Figure 5. Aortography: pseudoaneurysm of ascending aorta, in its distal portion. Presence of the transesophageal echocardiogram probe. Placement of the endoprosthesis in the ascending aorta through the aortic transvalvar, referenced by the pigTail catheter positioned in the right valsava sinus, to identify the right coronary ostium

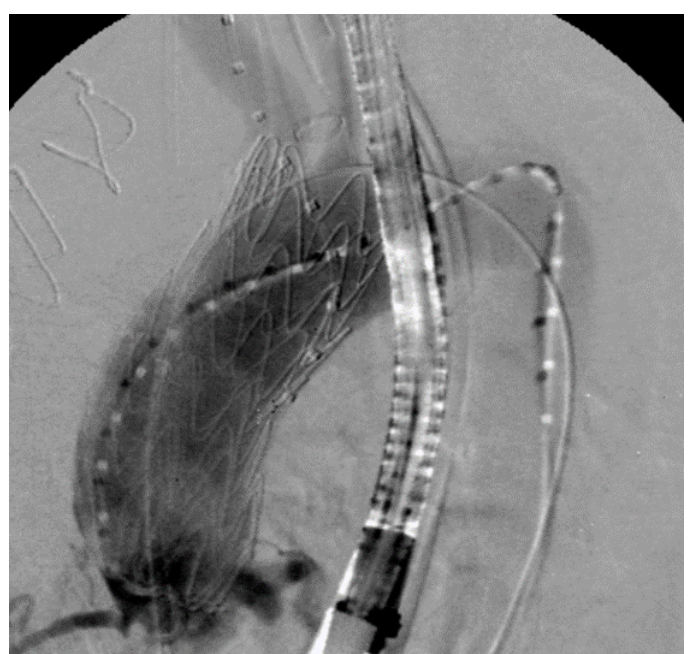

Figure 6. Aortography: Presence of the transesophageal echocardiogram probe. Release of the endoprosthesis in the ascending aorta via the aortic transvalvar, with filling of the right coronary ostia

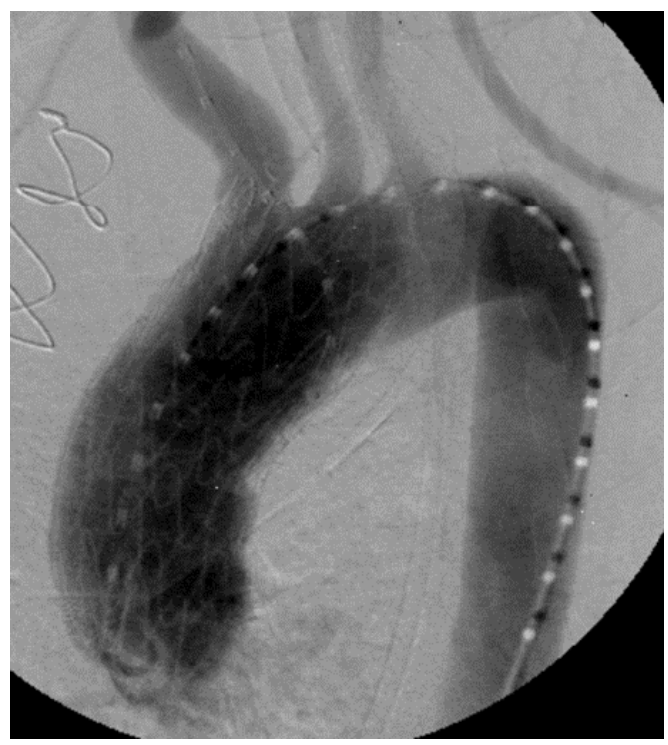

Figure 7. Aortography: occlusion of ascending aortic pseudoaneurysm by endoprosthesis

\section{Literature review}

\section{Discussion}

Pseudoaneurysm of ascending aorta is being reported in literature more frequently as single case and less frequently as series of cases. A systematic review published in 2014 of the period of 1980 to 2014 found 3044 citations with 355 treated pseudoaneurysms, 91, 5\% single case and $8,5 \%$ series of cases [1-45].

In regard to etiology, $76 \%$ of cases is due to previous cardiovascular surgery, particularly Surgery of the aorta, $5 \%$ thoracic trauma, $4,4 \%$ inflamatory; infectious; autoimune and 14,6\% undetermined [1-45].

Conventional Surgery should be well planned with alternative cannulation site (Femoral vessels; axillary artery) for cardiopulmonary by-pass, deep or moderate hypotermia Cardiopulmonary by-pass should be initiated before sternotomy in part of cases. Series of 10 to 60 cases report mortality of $6.7 \%$ to $46 \%$ and recurrence up to $12 \%$ within 10 years $[1,3-7,9,11-18,40,43]$. 
In regard to pseudoaneurysm after cardiovascular Surgery it has been reported to occur after coronary by-pass Surgery, valve Surgery, heart transplantation and specially after Surgery of the aorta. Its incidence varied from 0,5 to $13 \%$, higher frequency in follow up with image. The location of pseudoaneurysm is the site of aortic cannulation, cardioplegia infusion, aortic clamping, saphenous vein anastomosis and aortic sutures (Figure 10).

Due to high mortality and morbidity specially in acute clinical presentation, it is very attractive the possibility of percutaneous treatment of post cardíaca Surgery pseudoaneurysm. On the other hand, the treatment with Amplatzer septal occluder device. In the present case report the pseudoaneurysm was in the cannulation site in a reoperation of aortic valve surgery. Conventional surgery was performed with early recurrence. The percutaneous treatment was done with use of an endovascular prosthesis with early and medium term success. [2,10,19-21,23-39,41-45].

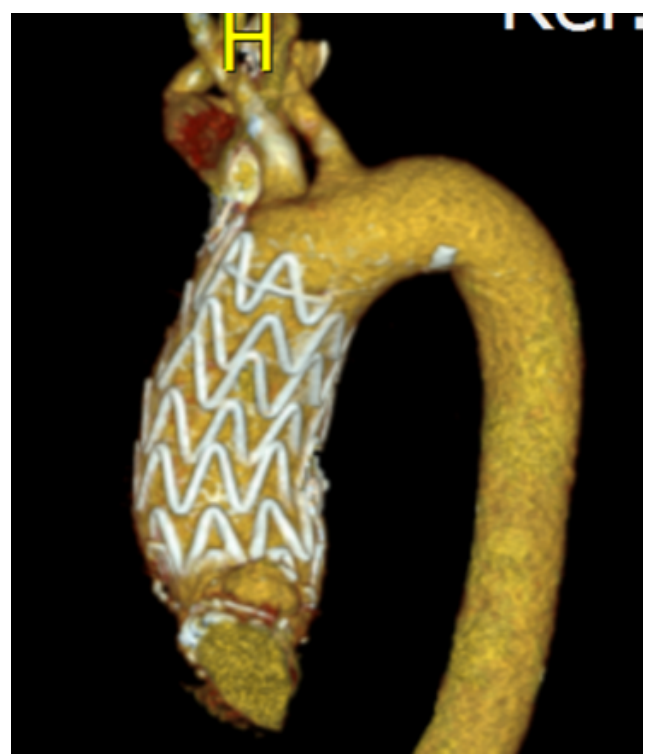

Figure 8. Computed angiotomography: occlusion of ascending aortic pseudoaneurysm by endoprosthesis

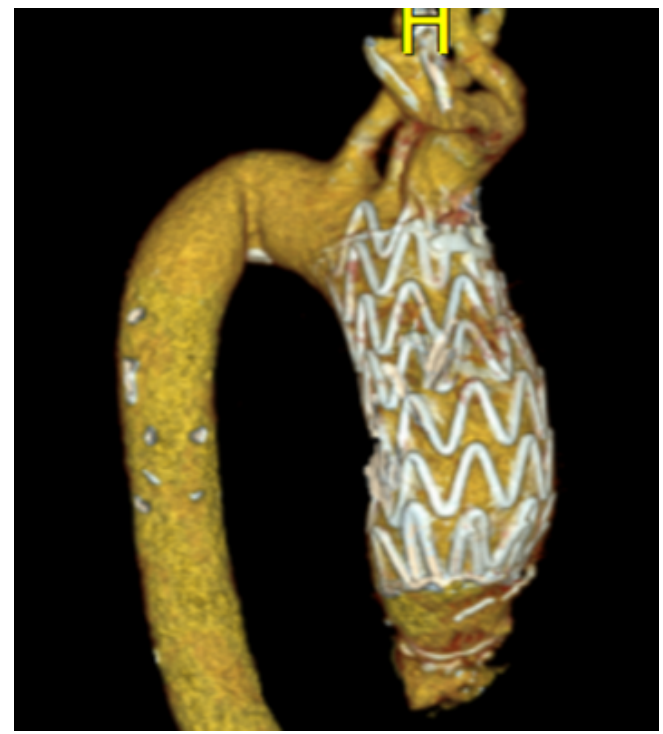

Figure 9. Computed angiotomography: occlusion of ascending aortic pseudoaneurysm by endoprosthesis

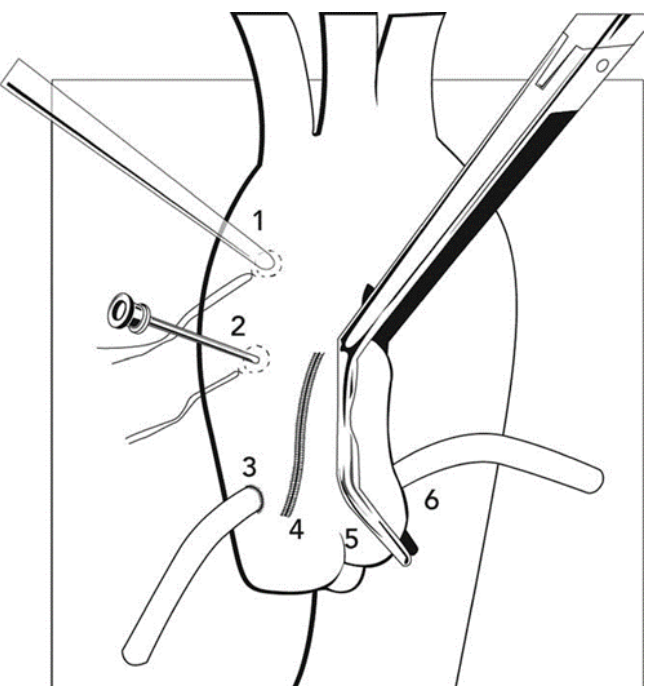

Figure 10. The location of the pseudoaneurysm is related to the site of cannulation (1) infusion site of cardioplegic solution (2), graft anastomosis (3), suture (4), aortic clamping (5) and aortic anastomosis (6).

\section{Conclusion}

This case report and literature review emphasizes the possibility of endovascular treatment of pseudoaneurysm after cardiovascular Surgery in particular cases.

\section{References}

1. Razzouk A, Gundry S, Wang N, Heyner R, Sciolaro C, et al. (1993) Pseudoaneurysms of the aorta after cardiac surgery or chest trauma. Am Surg 59: 818-823. [Crossref]

2. Deshpande A, Mossop P, Gurry J, Frydman G, Matalanis G, et al. (1998) Treatmen of traumatic false aneurysm of the thoracic aorta with endoluminal grafts. $J$ Endovasc Surg 5: 120-125. [Crossref]

3. Malvindi PG, van Putte BP, Heijmen RH, Schepens MA, Morshuis WJ (2010) Reoperations for aortic false aneurysms after cardiac surgery. Ann Thorac Surg 90 1437-1443. [Crossref]

4. Di Eusanio M, Berretta P, Bissoni L, Petridis FD, Di Marco L, et al. (2011) Reoperations on the proximal thoracic aorta: results and predictors of short- and long-term mortality in a series of 174 patients. Eur J Cardiothorac Surg 40: 1072-1076.

5. Katsumata T, Moorjani N, Vaccari G, Westaby S (2000) Mediastinal false aneurysm after thoracic aortic surgery. Ann Thorac Surg 70: 547-552. [Crossref]

6. Tang GH, Pinney SP, Broumand SR, Adams DH, Anyanwu AC (2011) Excellent outcomes with use of synthetic vascular grafts for treatment of mycotic aortic pseudoaneurysms after heart transplantation. Ann Thorac Surg 92: 2112-2116. [Crossref]

7. Navaravong L, Saab F, Cook JR, Peterman M, Flack J (2011) Ascending aortic pseudoaneurysm, a ticking bomb after cardiac surgery. Cardiovasc Revasc Med 12 177-180. [Crossref]

8. Agrifoglio M, Pontone G, Andreini D, Biglioli P, Cheema FH, et al. (2011) Conservative management of the pseudoaneurysms of ascending aortic graft: a case of spontaneous regression at follow-up. J Cardiovasc Med (Hagerstown) 12: 586-588. [Crossref]

9. D'Attellis N, Diemont FF, Julia PL, Cardon C, Fabiani JN (2001) Management of pseudoaneurysm of the ascending aorta performed under circulatory arrest by portaccess. Ann Thorac Surg 71: 1010-1011. [Crossref]

10. Szeto WY, Moser WG, Desai ND, Milewski RK, Cheung AT, et al. (2010) Transapical deployment of endovascular thoracic aortic stent graft for an ascending aortic pseudoaneurysm. Ann Thorac Surg 89: 616- 618. [Crossref]

11. Atik FA, Navia JL, Svensson LG, Vega PR, Feng J, et al. (2006) Surgical treatment of pseudoaneurysm of the thoracic aorta. J Thorac Cardiovasc Surg 132: 379-385. [Crossref]

12. Settepani F, Muretti M, Barbone A, Citterio E, Eusebio A, et al. (2008) Reoperation for aortic false aneurysms: our experience and strategy for safe resternotomy. J Card Surg 23: 216-220. [Crossref] 
13. Mohammadi S, Bonnet N, Leprince P, Kolsi M, Rama A, et al. (2005) Reoperation for false aneurysm of the ascending aorta after its prosthetic replacement: surgical strategy. Ann Thorac Surg 79: 147-152. [Crossref]

14. Schepens MA, Dossche KM, Morshuis WJ (1999) Reoperations on the ascending aorta and aortic root: pitfalls and results in 134 patients. Ann Thorac Surg 68: 1676-1680. [Crossref]

15. Sullivan KL, Steiner RM, Smullens SN, Griska L, Meister SG (1988) Pseudoaneurysm of the ascending aorta following cardiac surgery. Chest 93: 138-143. [Crossref]

16. Villavicencio MA, Orszulak TA, Sundt TM 3rd, Daly RC, Dearani JA, et al. (2006) Thoracic aorta false aneurysm: what surgical strategy should be recommended? Ann Thorac Surg 82: 81-89. [Crossref]

17. Kirsch EW, Radu NC, Mekontso-Dessap A, Hillion ML, Loisance D (2006) Aortic root replacement after previous surgical intervention on the aortic valve, aortic root, or ascending aorta. J Thorac Cardiovasc Surg 131: 601-608. [Crossref]

18. Dumont E, Carrier M, Cartier R, Pellerin M, Poirier N, et al. (2004) Repair of aortic false aneurysm using deep hypothermia and circulatory arrest. Ann Thorac Surg 78 : 117-120. [Crossref]

19. Yuri K, Yamaguchi A, Hori D, Nemoto K, Kawaguchi S, et al. (2010) A fenestrated stent graft for endovascular repair of an ascending aortic pseudoaneurysm. Ann Vasc Dis 3: 228-231. [Crossref]

20. Kim SW, Lee do Y, Kim MD, Won JY, Park SI, et al. (2014) Outcomes of endovascular treatment for aortic pseudoaneurysm in Behcet's disease. J Vasc Surg 59: 608-614. [Crossref]

21. Gray BH, Langan EM 3rd, Manos G, Bair L, Lysak SZ (2012) Technical strategy for the endovascular management of ascending aortic pseudoaneurysm. Ann Vasc Surg 26: 734-738. [Crossref]

22. van Prehn J, Vincken KL, Muhs BE, Barwegen GK, Bartels LW, et al. (2007) Toward endografting of the ascending aorta: insight into dynamics using dynamic cine- CTA. $J$ Endovasc Ther 14: 551-560. [Crossref]

23. Zago AC, Saadi EK, Zago AJ (2011) Endovascular approach to treat ascending aortic pseudoaneurysm in a patient with previous $\mathrm{CABG}$ and very high surgical risk. Catheter Cardiovasc Interv 78: 551-557. [Crossref]

24. Vaughan-Huxley E, Hamady MS, Metcalfe MJ, Adams B, Kashef E, et al. (2011) Endovascular repair of an acute, mycotic, ascending aortic pseudoaneurysm. Eur J Vasc Endovasc Surg 41: 488-491.

25. Heye S, Daenens K, Maleux G, Nevelsteen A (2006) Stent-graft repair of a mycotic ascending aortic pseudoaneurysm. J Vasc Interv Radiol 17: 1821-1825. [Crossref]

26. Rayan SS, Vega JD, Shanewise JS, Kong LS, Chaikof EL, et al. (2004) Repair of mycotic aortic pseudoaneurysm with a stent graft using transesophageal echocardiography. $J$ Vasc Surg 40: 567-570. [Crossref]

27. Saito N, Kimura T, Odashiro K, Toma M, Nobuyoshi M, et al. (2005) Feasibility of the Inoue single-branched stent-graft implantation for thoracic aortic aneurysm or dissection involving the left subclavian artery: short- to medium-term results in 17 patients. J Vasc Surg 41: 206-212. [Crossref]

28. Kpodonu J, Wheatley GH 3rd, Williams JP, Rodriguez-Lopez JA, Ramaiah VG, et al. (2008) A novel approach for the endovascular repair of the small thoracic aorta: customizing off- the-shelf endoluminal grafts to treat a post-coarctation pseudoaneurysm. Ann Thorac Surg 85: 1115-1117. [Crossref]
29. Taurino M, Fantozzi C, Stella N, Rizzo L (2013) Hybrid treatment of anastomotic pseudoaneurysm of the isthmus portion of the thoracic aorta. J Vasc Surg 58: 1088. [Crossref]

30. Barbetakis N, Xenikakis T, Efstathiou A, Fessatidis I (2007) Percutaneous coil embolisation of a false aortic aneurysm following coronary surgery and mediastinitis Hellenic J Cardiol 48: 246-248. [Crossref]

31. Chapot R, Aymard A, Saint-Maurice JP, Bel A, Merland JJ, et al. (2002) Coil embolization of an aortic arch false aneurysm. J Endovasc Ther 9: 922-925. [Crossref]

32. Al-Husami WF, Piemonte T (2008) Percutaneous repair of a pseudoaneurysm associated with coarctation of the aorta. J Invasive Cardiol 20: E293-E295. [Crossref]

33. Faganello G, Hamilton M, Wilde P, Turner MS (2008) Percutaneous closure of false aneurysms of the aorta in Wiskott Aldrich syndrome. Eur Heart J 29: 6. [Crossref]

34. Kumar PV, Alli O, Bjarnason H, Hagler DJ, Sundt TM, et al. (2012) Percutaneous therapeutic approaches to closure of cardiac pseudoaneurysms. Catheter Cardiovasc Interv 80: 687-699. [Crossref]

35. Lin PH, Bush RL, Tong FC, Chaikof E, Martin LG, et al. (2001) Intra-arterial thrombin injection of an ascending aortic pseudoaneurysm complicated by transient ischemic attack and rescued with systemic abciximab. J Vasc Surg 34: 939-942. [Crossref]

36. Perek B, Urbanowicz T, Zabicki B, Puslecki M, Juszkat R, et al. (2011) CT-guided thrombin injection to control rapid expansion of ascending aortic false aneurysm 15 months after Bentall-Bono operation. Cardiovasc Intervent Radiol 34: S83-S85. [Crossref]

37. Noble S, Ibrahim R (2012) Embolization of an Amplatzer mVSD occluder device used for percutaneous closure of an ascending aortic pseudoaneurysm: case report and literature review. Catheter Cardiovasc Interv 79: 334-338. [Crossref]

38. Hashizume K, Shimizu H, Koizumi K, Inoue S (2013) Endovascular aneurysm repair using the periscope graft technique for thoracic aortic anastomotic pseudoaneurysm. Interact Cardiovasc Thorac Surg 16: 553-555. [Crossref]

39. Kanani RS, Neilan TG, Palacios IF, Garasic JM (2007) Novel use of the Amplatzer septa occluder device in the percutaneous closure of ascending aortic pseudoaneurysms: a case series. Catheter Cardiovasc Interv 69: 146-153. [Crossref]

40. Bibiloni Lage I, Benussi S, Verzini A, Alfieri O (2012) Amplatzer device migration through the sternum: a rare complication of percutaneous treatment for an aortic pseudoaneurysm solved by 2 length-adjustable bovine pericardium conduits. $J$ Thorac Cardiovasc Surg 144: e27-e28.

41. Hussain J, Strumpf R, Wheatley G, Diethrich E (2009) Percutaneous closure of aortic pseudoaneurysm by Amplatzer occluder device- case series of six patients. Catheter Cardiovasc Interv 73: 521-529. [Crossref]

42. Westaby S, Luthra S, Anthony S, Ormerod O, Wilson N (2012) Amplatzer device deployment for saccular aortic arch aneurysm: a note of caution. Circulation 125: 1318 1320. [Crossref]

43. Attia R, Venugopal P, Whitaker D, Young C (2010) Management of a pulsatile mas coming through the sternum. Pseudoaneurysm of ascending aorta 35 years after repair of tetralogy of Fallot. Interact Cardiovasc Thorac Surg 10: 820-822. [Crossref]

44. Garg N, Bacharach JM, Reynolds TR (2011) Endovascular repair of ascending aortic pseudoaneurysm. Ann Vasc Surg 25: 696.e1-696.e5. [Crossref]

45. Patel AV, Gupta S, Laffin LJ, Retzer EM, Dill KE, et al. (2014) One size does not fit all: case report of two percutaneous closures of aortic pseudoaneurysm and review of the literature. Cardiovasc Revasc Med 15: 160-164. [Crossref]

Copyright: $(02018$ Barbieri LR. This is an open-access article distributed under the terms of the Creative Commons Attribution License, which permits unrestricted use, distribution, and reproduction in any medium, provided the original author and source are credited. 